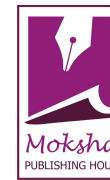

Research Article

www.ijrap.net

\title{
ASSESSMENT OF EFFECTIVE POTENTIALITY OF AQUEOUS LEAF EXTRACT OF HOLY BASIL (OCIMUM TENUIFLORUM L.) ON GROWTH AND CELL DIVISION OF GRASS PEA (LATHYRUS SATIVUS L.)
}

Prasanna Dutta, Ankita Pramanik and Animesh Kumar Datta *

Department of Botany, Cytogenetics, Genetics and Plant Breeding Section, University of Kalyani, Kalyani 741235, West Bengal, India

Received on: 27/08/15 Revised on: 29/09/15 Accepted on: 08/10/15

*Corresponding author

E-mail: dattaanimesh@gmail.com

DOI: $10.7897 / 2277-4343.07141$

\begin{abstract}
The effective potentiality of aqueous leaf extract (AE) of holy basil green type (Ocimum tenuiforum L., Family: Lamiaceae, 2n=36; scented branched herb) has been tested on colchicine treated $(0.25 \%, 8 \mathrm{~h})$ seeds of grass pea (Lathyrus sativus L.; Family: Fabaceae) at different concentrations (10.0, 20.0, 40.0, 80.0 and 100.0 per cent solution). The objective of the study is to foresee whether AE possesses the effectivity to inhibit colchicine induced enhancement of growth, cell division frequency and polyploid cell formation in a plant model, and the result obtained is promising in that direction. The result suggests that $\mathrm{AE}$ can be useful as an anti-cancerous extract, which however needs further evaluation.
\end{abstract}

KEYWORDS: Aqueous leaf extract; colchicine treatment; mitotic index; polyploid cell frequency; anti-cancerous

\section{INTRODUCTION}

Ocimum tenuiflorum L. (Family: Lamiaceae; common nameholy basil) possesses fragrance due to presence of essential oil (eugenol; methyl clavicol; 1,8 -cincole and $\alpha$ and $\beta$-bisabolene ${ }^{1}$ ) in leaves, flower and stem. The species (mostly leaves, also stem, flowers, roots, seeds and even whole plant) possesses immense significance for therapeutic uses ${ }^{2}$ especially in ayurvedic medicine where it is known as 'elixir of life' and believed to promote longevity ${ }^{3}$. The species also possesses antifungal $^{4}$, anti-microbial ${ }^{5}$, anti-fertility ${ }^{2}$, anti-diabetic ${ }^{6}$, hepatoprotective $^{7}$, cardio protective ${ }^{8}$ adaptogenic and anti-oxidant ${ }^{9,10}$ properties apart from other uses ${ }^{11}$, thereby highlighting its potentiality as source of bio-active compounds.

Ethanolic (anti-diabetic ${ }^{12}$ ), methanolic (anti-inflamatory ${ }^{13}$; gastro-protective $\left.{ }^{14}\right)$, hydroalcoholic (cardioprotective ${ }^{15}$ ) and aqueous (immunomodulatory ${ }^{16}$; radioprotective ${ }^{17}$ ) leaf extracts (AE) were tested for different pre-clinical activities using animal models. Both aqueous (topically) and ethanolic (orally) leaf extracts are found chemopreventive against 7, 12-dimethyl benzaanthracene induced hamster buccal pouch carcinogenesis ${ }^{18}$. However, such studies are rather meagre in in vivo system using plant as model. Samanta et al. ${ }^{19,20}$ reported that plant species like Lathyrus sativus L. (readily grown all throughout the year, low chromosome number $2 n=14$ with good stainability) can be used as model for preliminary screening of novel anti-cancerous drugs.

The present study describes the effectivity of aqueous leaf extract of $O$. tenuiflorum (green type-holy basil) on germinating grass pea (L. sativus) seeds (prior treatment of seeds with aqueous solution- $0.25 \%$ Colchicine for $8 \mathrm{~h}$ duration in each case) in relation to germination frequency, seedling growth, mitotic index and polyploid cell frequency. Prior treatment of seeds with colchicine will induce polyploid cell formation by depolymerising microtubules ${ }^{21}$. Uncontrolled polyploidy is an essential attribute associated with cancer development. The objective of the present study is to foresee whether aqueous leaf extract of holy basil can inhibit induced polyploidy using plant system as model (cost effective, convenient to use with no ethical barriers) and be considered as potent extract against cancer.

\section{MATERIALS AND METHODS}

\section{Preparation of Aqueous Extract (AE)}

Fresh leaves of $O$. tenuiflorum L. (green type) collected from University of Kalyani campus (Nadia, West Bengal) during the month of February, were cut into pieces and dried in hot air oven $\left(40{ }^{\circ} \mathrm{C} \pm 1{ }^{\circ} \mathrm{C}\right)$ for $48 \mathrm{~h}$, crushed with a mortar and pastel and the dusts were stored at $-20^{\circ} \mathrm{C}$ for subsequent uses. Dust of $20 \mathrm{~g}$ was suspended in $20 \mathrm{ml}$ distilled water thoroughly using magnetic stirrer $(100 \%)$. The content was then taken in clean beaker and boiled at $80{ }^{\circ} \mathrm{C} \pm 1{ }^{\circ} \mathrm{C}$ for about $30 \mathrm{~h}$ duration in a water bath. The crude extract was then filtered in a Whatman ${ }^{\circ}$ filter paper no. 42 and the supernatant was kept as stock solution and dilutions were made in double distilled water.

\section{Plant Material and Treatments}

Basil has great variation in chromosome number and therefore meiotic analysis (inflorescence fixed at $4.00 \mathrm{pm}$ to $5.00 \mathrm{pm}$ in Carnoy's fixative for $48 \mathrm{~h}$ following one change after $24 \mathrm{~h}$; PMC squashes were made in $2 \%$ propionocarmine solution) was performed to ascertain the chromosome number of the species under consideration.

Dry filled seeds of L. sativus (Family: Fabaceae, common name: grass pea) were surface sterilized $\left(0.1 \% \mathrm{HgCl}_{2}\right)$ for $5 \mathrm{mins}$, washed with distilled water ( 3 times, 10 mins each) and treated with aqueous solution of colchicine $(0.25 \%)$ for $8 \mathrm{~h}$ in dark. The treated seeds were given a recovery period of $24 \mathrm{~h}$ in distilled water and then given in Petri plates lined with moist filter paper. The Petri plates were kept in controlled laboratory conditions $\left(18{ }^{\circ} \mathrm{C} \pm 1{ }^{\circ} \mathrm{C}\right)$ for germination. The germinated seeds 
(initiation of germination following bursting of seed coat) were soaked in $\mathrm{AE}$ (100.0, 80.0, 40.0, 20.0 and $10.0 \%$; 50 seeds in each lot) for $48 \mathrm{~h}$ duration. Dry seeds (A) and seeds treated with colchicine $(0.25 \%, 8 \mathrm{~h}-\mathrm{B})$ were kept as controls.

\section{Assessment of Seedling Length, Mitotic Index and Polyploid Cell Frequency}

Seedling length $(\mathrm{mm})$ was measured in a millimetre graph paper on $7^{\text {th }}$ day from treatment (randomly 8-10 seedlings were taken from each set and from each replica; 3 replicas were kept for each set including control A and B). Lethality and injury were calculated from germination frequency and seedling length respectively as per cent of controls (A and B) in accordance with Konzak et al. ${ }^{22}$. Seedling morphology was also studied.
Mitotic study was performed from germinating roots $(2 \mathrm{~mm})$ collected from control and treated materials, fixed in 1:3 acetic alcohol (v/v) for overnight and preserved in $70 \%$ alcohol under refrigeration for subsequent uses. The roots $(2$ per slide and 3 slides for each set) were stained in $2 \%$ orcein- $\mathrm{HCl}(1 \mathrm{~N})$ mixture and the root tips were squashed in $45 \%$ acetic acid. Mitotic index (MI) was calculated using the formula: $\mathrm{MI}=$ (dividing cells / total number of cells) $\times 100$. Frequency of polyploid cells was estimated from dividing cells. Data obtained for seedling length, frequency of dividing cells and that of polyploid cells were statistically analyzed using F-test and by computing critical difference (CD) to assess significant variation, if any, between/among treatments. Photomicrographs were taken from suitable cytological preparation.

Table 1: Physiological and cytological attributes studied in $L$. sativus

\begin{tabular}{|c|c|c|c|c|c|c|c|c|c|}
\hline \multirow[t]{2}{*}{ Doses (\%) } & \multirow{2}{*}{$\begin{array}{l}\text { No. of } \\
\text { seeds } \\
\text { given }\end{array}$} & \multirow{2}{*}{$\begin{array}{c}\text { Germination } \\
\text { frequency }(\%)\end{array}$} & \multirow{2}{*}{$\begin{array}{c}\text { Seedling } \\
\text { length on } 7^{\text {th }} \\
\text { day }(\mathrm{mm})\end{array}$} & \multirow[t]{2}{*}{ "Lethality } & \multirow[t]{2}{*}{ "Injury } & \multicolumn{4}{|c|}{ Cytological attributes } \\
\hline & & & & & & $\begin{array}{c}\text { No. of } \\
\text { cells } \\
\text { assessed }\end{array}$ & $\begin{array}{c}\text { No. of } \\
\text { dividing } \\
\text { cells }\end{array}$ & $\begin{array}{c}\text { Mitotic } \\
\text { index } \\
(\%)\end{array}$ & $\begin{array}{c}\text { Frequency of } \\
\text { polyploid cells } \\
(\%)\end{array}$ \\
\hline Control A & 50 & 84.00 & $11.10 \pm 0.63$ & - & - & 9104 & 451 & 4.95 & 0.00 \\
\hline Control B & 50 & 94.00 & $10.60 \pm 0.34$ & - & - & 8000 & 640 & 8.00 & 75.50 \\
\hline $\mathrm{B}+10.0$ & 50 & 90.00 & $9.90 \pm 0.26$ & $\begin{array}{c}- \\
(4.25)\end{array}$ & $\begin{array}{l}10.81 \\
(6.60)\end{array}$ & 7833 & 416 & 5.31 & 71.10 \\
\hline $\mathrm{B}+20.0$ & 50 & 90.00 & $7.90 \pm 0.45$ & $\begin{array}{c}- \\
(4.25)\end{array}$ & $\begin{array}{c}28.83 \\
(25.51)\end{array}$ & 6515 & 355 & 5.45 & 61.90 \\
\hline $\mathrm{B}+40.0$ & 50 & 100.00 & $9.70 \pm 0.44$ & - & $\begin{array}{l}12.60 \\
(8.53)\end{array}$ & 6100 & 340 & 5.57 & 52.00 \\
\hline $\mathrm{B}+80.0$ & 50 & 84.00 & $9.10 \pm 0.86$ & - & $\begin{array}{c}18.10 \\
(14.13)\end{array}$ & 6000 & 355 & 5.92 & 47.00 \\
\hline $\mathrm{B}+100.0$ & 50 & 100.00 & $10.00 \pm 0.31$ & - & $\begin{array}{c}9.90 \\
(5.70)\end{array}$ & 8239 & 400 & 4.85 & 31.00 \\
\hline at $5 \%$ lev & & & 0.66 & & & & & 0.08 & 0.78 \\
\hline
\end{tabular}

*Per cent of control; values in parenthesis are in relation to control B
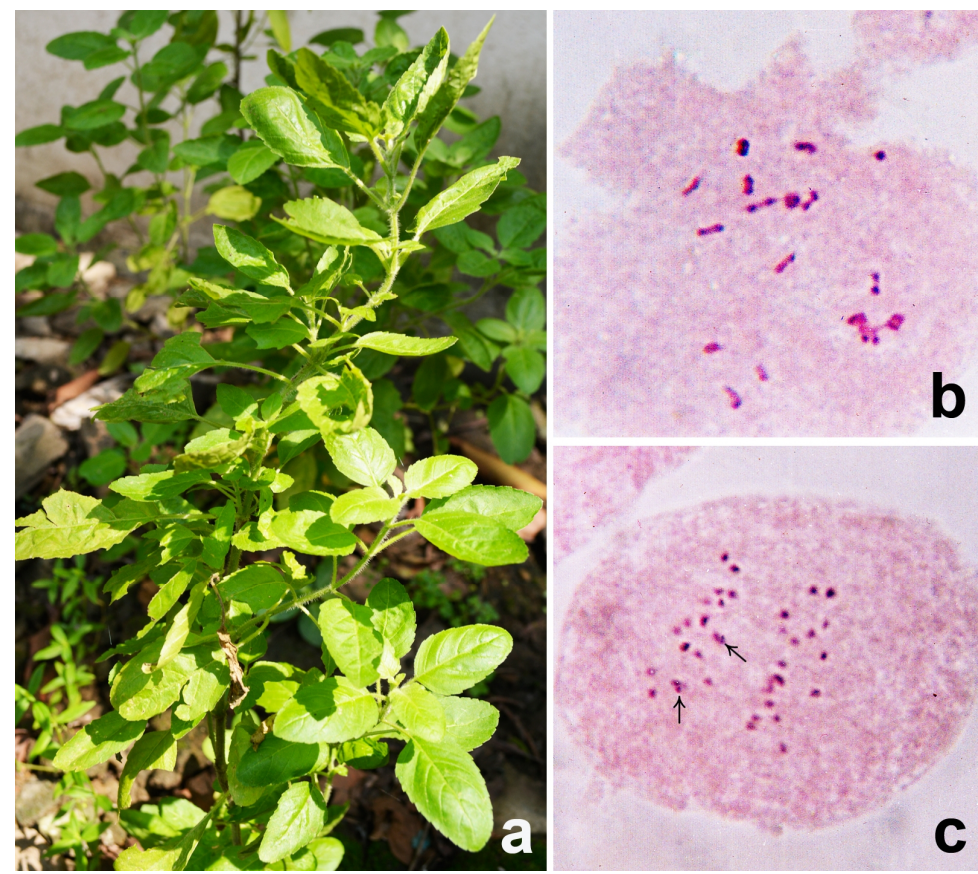

Figure 1a: A mature twig of $O$. tenuiflorum, b: $18 I$ at metaphase $I(2 \mathrm{n}=36)$, c: $18 / 18$ separation of chromosomes at anaphase $\mathrm{I}(\rightarrow$ indicates overlapping chromosomes) 


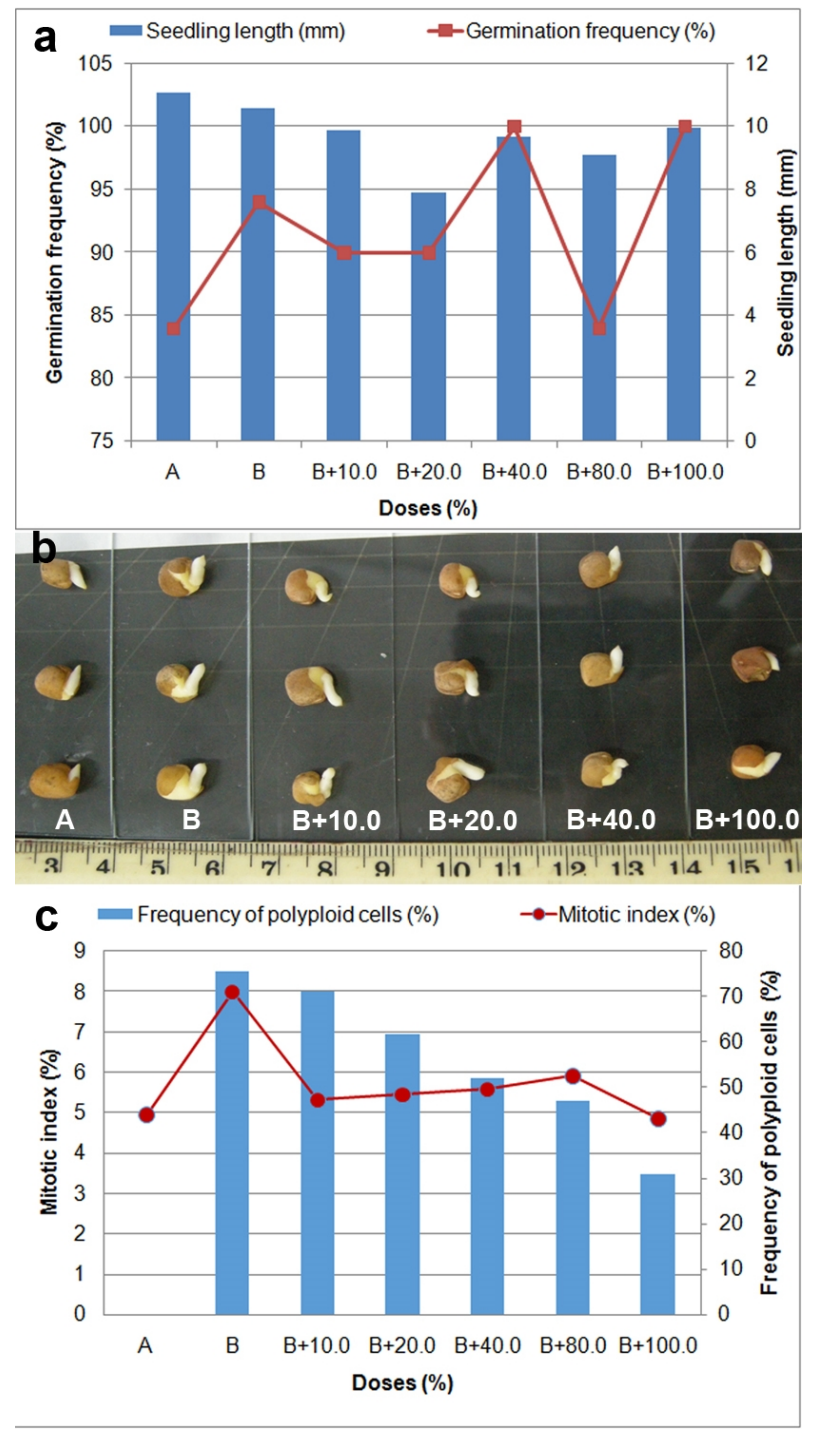

Figure 2a: Germination frequency and seedling length in control(s) and treated samples, b: bulging of radicle length in control B and its phenotypic changes in different concentrations, $c$ : mitotic index and frequency of polyploid cells in control(s) and treatments

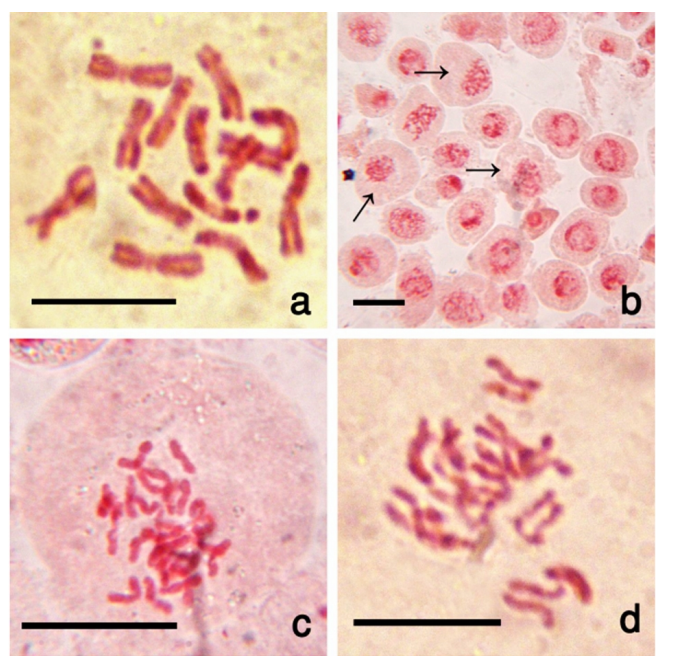

Figure 3a: Metaphase showing $2 \mathrm{n}=14$ chromosomes in control $\mathrm{A}$, b: enhancement in cell and nuclear volume in control B, c-d: metaphase cells with $2 \mathrm{n}>14$ chromosomes in control B (scale bar $=25 \mu \mathrm{m}$ ) 


\section{RESULTS AND DISCUSSION}

O. tenuiflorum is an erect, scented and branched herb (Figure 1a). The chromosome number assessed has been $2 n=36$ always predominantly $18 \mathrm{II}$ at metaphase-I (Figure 1b) and 18/18 segregation of chromosomes in anaphase-I cells (Figure 1c). The chromosome number in the species is in accordance with earlier reports $^{23-25}$ thereby authenticating the identity of the species. Mukherjee and Datta ${ }^{25}$ opined that basic chromosome number in basil including $O$. tenuiflorum is $\mathrm{x}=12$ with probable origin from primitive base number $\mathrm{x}=6$ through polyploidization event.

Physiological and cytological attributes are presented in Table 1 and Figure 2a-c. In relation to control A $(84.0 \%)$ and control B $(94.0 \%)$ germination frequency in $\mathrm{AE}$ treatments ranges from $84.0 \%(80 \% \mathrm{AE})$ to $100.0 \%(40$ and $100 \% \mathrm{AE})$. Effect reflected for germination frequency is not marked between/among doses including controls. Colchicine treatments (control B) induced bulging of radicle tips and it shows diminishing tendency with AE treatments (Figure 2b). Radicals are phenotypically normal from $80.0 \% \mathrm{AE}$ treatment onwards. Seedling length is $11.1 \mathrm{~mm} \pm 0.63$ in control A and $10.6 \mathrm{~mm} \pm$ 0.34 in control B and it decreases significantly $(\mathrm{p}<0.05)$ in $\mathrm{AE}$ treatments (excepting: $100.0 \% \mathrm{AE}$ as compared to control $\mathrm{B}$ ). Decrease in seedling length is not dose dependent. Lethality and injury are also noted in some doses of treatment.

Frequency of dividing cells enhanced significantly $(\mathrm{p}<0.05)$ in colchicine treated seeds $(8.0 \%$; control B) than dry control $(4.95 \%$; control A). Significant $(\mathrm{p}<0.05)$ reduction in mitotic index $(4.85 \%-100.0 \% \mathrm{AE}$ to $5.92 \%-80.0 \% \mathrm{AE})$, though not dose dependent, has been studied following $\mathrm{AE}$ treatments in relation to control $\mathrm{B}$ (Figure 2c). Frequency of dividing polyploid cell is $0.0 \%$ in control A and $75.5 \%$ in control B. Dose dependent decrease (significant-p $<0.05$ ) in polyploid cells frequency has been studied following $\mathrm{AE}$ treatments. Control B also shows enhancement in cell and nuclear volume, which also reduces following $\mathrm{AE}$ treatment (Figure 3a-d).

Thus aqueous leaf extract of holy basil (green type) possesses the potentiality to inhibit growth, cell division and polyploid cell formation, attributes associated with cancer. Such inhibitory action on cell division possibly caused due to DNA interaction during replication by different anti-cancerous drugs namely, methotrexate ${ }^{19,26-29}$, vinblastine ${ }^{30}$, etoposide ${ }^{20}$, cisplatin $^{20}$ among others have also been reported in plant system. Karthikeyan et $a l .{ }^{18}$ suggested that administration of aqueous and ethanolic extract of $O$. sanctum to mice bearing Sarcoma-180 solid tumour mediated a significant reduction in tumour volume and increase in life span.

The present investigation signifies 1) aqueous leaf extract of holy basil possesses the potentiality to inhibit growth and cell division and can be a source of anti-cancerous agent; however, active constituent(s) associated to it needs identification and 2) plant system can be used as model for preliminary screening of such plant extracts. Plant system is rather convenient to use and cost effective.

\section{ACKNOWLEDGEMENT}

The authors are thankful to Dr. Aninda Mandal and Shri Debadrito Das, Department of Botany, University of Kalyani for their academic support.

\section{REFERENCES}

1. Laakso I, Laakso TS, Wolf BH, Kuhnel N, Knobloch K. Constituents of the essential oil from the holy basil or tulsi plant, Ocimum sanctum. Plant Medica 1990; 56: 527. http://dx.doi.org/10.1055/s-2006-961084

2. Prakash P, Gupta N. Therapeutic uses of Ocimum sanctum Linn. (Tulsi) with a note on eugenol and its pharmacological actions: a short review. Indian J Physiol Pharmacol 2005; 49: $125-131$.

3. Datta AK, Mukherjee M, Bhattacharya A, Saha A, Mandal A, Das A. The basils-an overview. J Trop Med Plants 2010; 11: 231-241

4. Khan A, Ahmad A, Manzoor N, Khan LA. Antifungal activities of Ocimum sanctum essential oil and it lead molecules. Nat Prod Commun 2010; 5: 345-349.

5. Ahonkhai I, Ba A, Edogun O, Mu U. Antimicrobial activities of the volatile oils of Ocimum basilicum L. and Ocimum gratissimum L. (Lamiaceae) against some aerobic dental isolates. Pak J Pharm Sci 2009; 22: 405-409.

6. Rai V, Mani UV, Iyer UM. Effect of Ocimum sanctum leaf powder in blood lipoproteins, glycated proteins and total amino acids in patients with non-insulin-dependent diabetes mellitus. J Nutr Environ Med 1997; 7: 113-118. http://dx.doi .org/10.1080/13590849762709

7. Meera R, Devi P, Kameswari B, Madhumitha B, Merlin NJ. Antioxidant and hepatoprotective activities of Ocimum basilicum Linn. and Trigonella foenum-graecum Linn. against $\mathrm{H}_{2} \mathrm{O}_{2}$ and $\mathrm{CCl}_{4}$ induced hepatotoxicity in goat liver. Indian J Exp Biol 2009; 47: 584-590.

8. Sharma M, Kishore K, Gupta SK, Joshi S, Arya DS Cardioprotective potential of Ocimum sanctum in isoproterenol induced myocardial infarction in rats. Mol Cell Biochem 2001; 225: 75-83. http://dx.doi.org/10.1023 /A:1012220908636

9. Sethi J, Sood S, Seth S, Talwar A. Evaluation of hypoglycemic and antioxidant effect of Ocimum sanctum. Indian J Clinical Biochem 2004; 19: 152-155. http://dx.doi. org/10.1007/BF02894276

10. Shilpa K, Selvakkumar C, Senthil AK, Lakshmi BS. In vitro root culture of Ocimum sanctum Linn. and evaluation of its free radical scavenging activity. Plant Cell Tissue Org Cult 2010; 101: 105-109. http://dx.doi.org/10.1007/s11240-0099661-4

11. Pattanayak P, Behera P, Das D, Panda SK. Ocimum sanctum Linn. a reservoir plant of therapeutic application an overview. Pharmacogn Rev 2010; 4: 95-105. http://dx.doi.org/10.4103/0973-7847.65323

12. Narendhirakannan RT, Subramanian S, Kandaswamy M. Biochemical evaluation of antidiabetogenic properties if some commonly used Indian plants on streptozotocininduced diabetes in experimental rates. Clinical Exp Pharmacol Physiol 2006; 33: 1150-1157. http://dx.doi.org/ 10.1111/j.1440-1681.2006.04507.x

13. Godhwani S, Godhwani JL, Vyas DS. Ocimum sanctum - an experimental study evaluating its antiinflamatory, analgesic and antipyretic activity in animals. J Ethnopharmacol 1987; 21: 153-163. http://dx.doi.org/10.1016/0378-8741(87) 90125-5

14. Goel RK, Sairam K, Dorababu M, Prabha T, Rao ChV. Effect of standardized extract of Ocimum sanctum Linn. on gastric mucosal offensive and defensive factors. Indian J Exp Bio 2005; 43: 715-721.

15. Sood S, Narang D, Thomas MK, Gupta YK, Maulik SK. Effect of Ocimum sanctum Linn. on cardiac changes in rats subjected to chronic restraint stress. J Ethnopharmacol 2006; 108: 423-427. http://dx.doi.org/10.1016/j.jep.2006.06.010 
16. Mediratta PK, Sharma KK, Singh S. Evalaution of immunomodulatory potential of Ocimum sanctum seed oil and its possible mechanism of action. $\mathrm{J}$ Ethnopharmacol 2002; 80: 15-20. http://dx.doi.org/10.1016/S0378-8741(01) 00373-7

17. Bhartiya US, Raut YS, Joseph LJ. Protective effect of Ocimum sanctum Linn. after high-dose 131 iodine exposure in mice: and in vivo study. Indian J Exp Bio 2006; 44: 647 652.

18. Kartikeyan K, Ravichandran P, Govinsamy S. Chemopreventive effect of Ocimum sanctum on DMBAinduced hamster buccal pouch carcinogenesis. Oral Oncols 1999; 35: 112-119. http://dx.doi.org/10.1016/S13688375(98) 00035-9

19. Samanta A, Datta S, Maity TR, Mandal A, Datta AK. Assessment of methotrexate on dihydrofolate reductase activity, total RNA content and cell division of Lathyrus sativus L. Nucleus 2014; 57: 129-134. http://dx.doi.org/ 10.1007/s13237-014-0115-y

20. Samanta A, Datta S, Datta AK, Maity TR, Mandal A, Das D. Assessment of cisplatin, etoposide, vinblastine and Piper betle leaf extract on some attributes of cell division in Lathyrus sativus L. Cytologia 2015; 80: In press. http://dx.doi.org/10.1508/cytologia.80.483

21. Caperta AD, Delgado M, Ressurreicao F, Meister A, Jones RN, Viegas W, Houben A. Colchicine-induced polyploidization depends on tubulin polymerization in cmetaphase cells. Protoplasma 2006; 227: 147-153. http://dx.doi.org/10.1007/s00709-005-0137-z

22. Konzak CF, Nilan RA, Wagner J, Foster RJ. Efficient chemical mutagenesis. The use of induced mutagenesis in plant breeding. Rad Bot 1965; 75: 49-70.

23. Bir SS, Saggoo MIS. In: chromosome number reports LXIX. Taxon 1980; 29: 703-713.
24. Mukherjee M, Datta AK. Secondary chromosome associations in Ocimum spp. Cytologia 2006; 71: 149-152. http://dx.doi.org/10.1508/cytologia.71.149

25. Suzuki N, Iwai K. The occurrence and properties of dihydrofolate reductase in pea seedling. Plant Cell Physiol 1970; 11: 199-208.

26. Cella R, Crosti P, Nielsen E, Parisi B. Biochemical basis of different sensitivity to methotrexate in Daucus carota and Oryza sativa cell cultures. J Exp Bot 1983; 34: 1189-1195. http://dx.doi.org/10.1093/jxb/34.9.1189

27. Prabhu V, Chatson KB, Lui H, Abrams GD, King J. Effects of sulfanilamide and methotrexate on 13C fluxes through the glycine decarboxylase/serine hydroxymethyltransferase enzyme system in Arabidopsis. Plant Physiol 1998; 116: 137-144. http://dx.doi.org/10.1104/pp.116.1.137

28. Loizeau K, De Brouwer V, Gambonnet B, Yu A, Renou JP, Straeten VD, Lambert WE, Rebeille F, Ravanel S. A genome-wide and metabolic analysis determined the adaptive response of Arabidopsis cells to folate depletion induced by methotrexate. Plant Physiol 2008; 148: 20832095. http://dx.doi.org/10.1104/pp.108.130336

29. Toso RJ, Jordan MA, Farrell KW, Matsumuto B, Wilson L. Kinetic stabilisation of microtubule dynamic instability in vitro by vinblastine. Biochem 1993; 32: 1285-1293. http://dx.doi.org/10.1021/bi00056a013

\section{Cite this article as:}

Prasanna Dutta, Ankita Pramanik and Animesh Kumar Datta. Assessment of effective potentiality of aqueous leaf extract of Holy basil (Ocimum tenuiflorum L.) on growth and cell division of Grass pea (Lathyrus sativus L.). Int. J. Res. Ayurveda Pharm. Jan - Feb 2016;7(Suppl 1):118-122 http://dx.doi.org/ $\underline{10.7897 / 2277-4343.07141}$

Disclaimer: IJRAP is solely owned by Moksha Publishing House - A non-profit publishing house, dedicated to publish quality research, while every effort has been taken to verify the accuracy of the content published in our Journal. IJRAP cannot accept any responsibility or liability for the site content and articles published. The views expressed in articles by our contributing authors are not necessarily those of IJRAP editor or editorial board members. 